\title{
Studi Eksploratif Kualitas Bukti Matematis pada Soal Aritmatika Matriks Berbasis Motivation to Reasioning Tasks
}

\author{
M. Zainudin \\ Program Studi Pendidikan Matematika FPMIPA IKIP PGRI Bojonegoro \\ Email: zain.akhmad@yahoo.com
}

\begin{abstract}
Abstrak
Hasil kajian eksploratif ini memaparkan kualitas bukti matematis oleh mahasiswa pada soal aritmatika matriks berbasis motivation to reasioning tasks. Metode penelitian yang digunakan adalah kualitatif dengan model grounded theory melalui 3 tahap yakni open coding, selective coding, dan theoretical coding. Pada akhir pembahasan sub bab aritmatika matriks pada matakuliah aljabar linier, mahasiswa mendapatkan tugas membuktikan 3 soal aritmatika matriks untuk mengukur kemampuan konstruksi bukti matematis. Mahasiswa dikelompokkan menjadi 3 tingkatan, yakni tinggi, sedang, dan rendah. Pada tahap open coding, dilakukan analisis hasil pekerjaan mahasiswa terhadap 3 soal tersebut untuk menentukan kategori yang relevan. Tahap selective coding dilakukan dengan menyeleksi dan pendalaman terhadap penemuan kategori melalui interview dengan responden yang diambil berdasarkan sampel teoritis (masing-masing tingkatan diambil 3 responden). Tahap theoretical coding ditemukan bahwa kualitas konstruksi bukti matematis dalam matakuliah aljabar linier pada soal aritmatika matriks dapat ditentukan berdasarkan 6 kategori, yakni langkah awal, alur pembuktian, ketaatan konsep, argumen, dan penggunaan kunci.
\end{abstract}

Kata kunci: bukti matematis, motivation to reasioning tasks, soal aritmatika matriks

\section{Pendahuluan}

Aljabar Linier merupakan salah satu matakuliah keilmuan dan keterampilan yang wajib ditempuh oleh mahasiswa program studi pendidikan matematika FPMIPA IKIP PGRI Bojonegoro. Salah satu materi dalam Aljabar Linier adalah aritmatika Matriks. Beberapa sifat operasi aritmatika untuk bilangan real juga berlaku untuk matriks tetapi ada yang tidak berlaku. Aturan aritmatika untuk bilangan real yang tidak berlaku untuk matriks adalah hukum komutatif perkalian (commutative law for multiplication). Sebarang bilangan real $a$ dan $b$, selalu berlaku $a b=b a$, tetapi untuk matriks, $A B$ dan $B A$ tidak selalu setara. Kesetaraan tidak terjadi karena: 1) kemungkinan pertama, hasil kali $A B$ dapat didefinisikan, tetapi $B A$ tidak dapat didefinisikan; 2) kemungkinan kedua, $A B$ dan $B A$ dapat didefinisikan, tetapi memiliki ordo yang berbeda; 3 ) kemungkinan ketiga adalah $A B \neq B A$, meskipun $A B$ dan $B A$ dapat didefinisikan dan memiliki ordo yang sama.

Hanna dalam [1] menyatakan bahwa pemahaman dalam matematika hendaknya dipromosikan melalui pembuktian matematika. Pembuktian 
pada dasarnya adalah membuat serangkaian deduksi dari asumsi (premis atau aksioma) dan hasil-hasil matematika yang sudah ada (lema atau teorema) untuk memperoleh hasil-hasil penting dari suatu persoalan matematika [2]; Schoenfeld dalam [3]. Hanna dalam [4] mengatakan bahwa pembelajaran matematika tanpa disertai dengan pembuktian tidak mencerminkan teori dan praktek bermatematika.

Bukti merupakan esensi dalam belajar matematika. Kajian matematika menekankan kebenaran berdasarkan induktif dan deduktif. Kebenaran induktif dapat dilakukan dengan menunjukkan contoh-contoh atau mensubstitusikan bilangan-bilangan pada aturan atau rumus tertentu. Kebenaran deduktif dalam matematika dapat dilakukan dengan pembuktian. Bukti mengandung proses untuk dikerjakan dan konsep matematika untuk dipikirkan [5]. Bukti mengandung prosedur penyusunan argumen dan makna pernyataan yang hendak dibuktikan [6]. Referensi [7] menyatakan bahwa menuliskan suatu bukti matematis akan membantu pemahaman peserta didik terhadap materi tersebut. Senada dengan pemikiran Reid dalam [8] menyatakan bahwa melatih siswa untuk menuliskan pembuktian matematis akan mengembangkan penalaran deduktif.

$$
\text { Referensi [2] menjelaskan }
$$

bahwa representasi bukti berkembang melalui empat tahapan, yaitu: bukti enaktif (enactive proof), bukti visual (visual proof), bukti simbolik (symbolic proof), dan bukti formal (formal proof). Bukti enaktif, melibatkan peragaan fisik untuk menunjukkan suatu kebenaran; bukti visual, melibatkan pembuatan grafik atau gambar; bukti simbolik, melibatkan pemanipulasian simbolsimbol aljabar; dan bukti formal melibatkan penalaran deduktif. Menurut Hanna dalam [4], ciri dari bukti formal adalah: (1) setiap definisi, asumsi, dan sistem aksioma yang mendasarinya dinyatakan secara eksplisit, (2) setiap langkah-langkah pembuktian disertai alasan deduktifnya. Selanjutnya, terutama berkenaan dengan diterimanya suatu teorema, Hanna dalam [9] memberikan suatu kriteria untuk bukti formal, yaitu harus memuat argumentasi-argumentasi yang meyakinkan dan akurat.

Penelitian dalam Indonesia Mathematics and Science Teacher Education Project (IMSTEP) yang dilakukan di Bandung pada tahun 1999 menghasilkan simpulan bahwa kegiatan bermatematika yang dipandang sulit oleh peserta didik untuk mempelajarinya dan guru untuk membelajarkannya antara lain adalah jastifikasi atau pembuktian [10]. Houdebine dalam [8] mengatakan bahwa pembuktian merupakan kegiatan yang paling kompleks dan menyulitkan peserta didik karena kelemahan dalam memahami struktur dasar penalaran deduktif. Ketika peserta didik menuliskan pembuktian, mereka sering kali mengalami kesalahan dalam mengurutkan langkah-langkah argumentatif.

Referensi [11] mengatakan bahwa seseorang dapat mengonstruksikan bukti dengan pendekatan referensial dan sintetik, tetapi mereka tidak memandang bukti sebagai prosep (proses dan konsep). Bukti sebagai prosep memiliki proses, konsep, dan simbol yang menyatakan proses maupun konsep tersebut. Simbol 
prosep bukti adalah redaksi teorema yang dibuktikan [12]. Proses bukti adalah pengembangan rangkaian bukti, sedangkan konsep bukti adalah makna yang terkandung dalam redaksi atau pernyataan yang dibuktikan.

Eddie Gray, David Olmer Tall [2] menjelaskan bahwa ada tiga tahap dalam pembuktian yaitu prosedur, proses dan pronsep.

...the meaning of symbols developed through a squence of activities: (a) prosedure where a finite succession of decisions and actions is built up into a coherent sequence, (b) process, where incresingly efficient ways become availeble to achieve the same result, noe seen as a whole, (c) procept, whe the symbols are conceived flexibily as processes to do and concepts to think about. Initially the individual builds an "action schema" (in the sense of
Piaget as a coordinated sequence of actions.

Tahap prosedur merupakan rangkaian beberapa keputusan dan aksi terbatas sedemikian hingga menjadi suatu rangkaian yang terpadu atau bertalian secara logis. Tahap proses merupakan aktivitas mental dimana cara-cara yang lebih efesien untuk mencapai hasil yang sama semakin terlihat sebagai satu kesatuan. Tahap prosep merupakan aktivitas mental dimana simbol dipahami secara fleksibel sebagai proses untuk dilakukan dan konsep untuk dipikirkan.

$$
\text { George Polya }
$$

menjelaskan bahwa pemecahan masalah untuk membuktikan dilakukan dengan 5 tahap, yakni identifikasi, mobilisasi dan reorganisasi pengetahuan, membuat rencana, aplikasi, looking back. Teory Gray-Tall dan Polya dapat dinyatakan secara ringkas sebagai berikut:

TABEL 1 TAHAP BERPIKIR MENGONSTRUKSI PROSEP MENURUT GRAY-TALL DAN PEMECAHAN MASALAH UNTUK MEMBUKTIKAN MENURUT POLYA

\begin{tabular}{|c|c|}
\hline Gray-Tall & Polya \\
\hline $\begin{array}{l}\text { 1. Prosedur } \\
\text { a. Mengingat set before, met } \\
\text { before } \\
\text { b. Mengerjakan secara prosedural } \\
\text { 2. Proses } \\
\text { a. Memahami prosedur } \\
\text { b. Mengerjakan beberapa cara } \\
\text { c. Menentukan cara efektif dan } \\
\text { efisien } \\
\text { d. Memaknai } \\
\text { menghubungkan makna setiap } \\
\text { langkah kerja } \\
\text { Prosep } \\
\text { a. Memahami proses dan konsep } \\
\text { sebagai satu item } \\
\text { b. Menghaluskan konsep } \\
\text { c. Memikirkan secara fleksibel } \\
\text { proses dan konsep } \\
\text { d. Memikirkan teorema secara } \\
\text { proseptual dan otomatis } \\
\text { (intuitif) }\end{array}$ & $\begin{array}{l}\text { 1. Identifikasi: hipotesis dan inklusi } \\
\text { 2. Mobilisasi dan reorganisasi } \\
\text { pengetahuan } \\
\text { 3. Membuat rencana } \\
\text { 4. Aplikasi } \\
\text { a. Melengkapi gambar sesuai } \\
\text { rencana } \\
\text { b. Menulis langkah-langkah bukti } \\
\text { c. Memeriksa satu langkah bukti } \\
\text { Looking back } \\
\text { a. Memeriksa kembali ketepatan } \\
\text { hasil dan argumen } \\
\text { b. Menyusun bukti dengan cara } \\
\text { berbeda Memilih cara efektif dan } \\
\text { ef. efisien secara } \\
\text { d. Menyatakan makna samblang dan sederhana }\end{array}$ \\
\hline
\end{tabular}


Referensi [14] memandang
rangkaian proses berpikir hingga menghasilkan kerja secara prosedural hanya satu tahap, tetapi [13] berpendapat bahwa pada pemecahan masalah untuk membuktikan hingga menghasilkan empat tahap. Referensi [15] memandang proses pembuktian satu tahap karena pada aritmatika, misalnya penjumlahan, identifikasi objek yang digunakan tidak perlu diberi perhatian. Perhatian diberikan pada prosedur aksi atas (misalnya menghitung) obyek-obyek tersebut. Identifikasi data prinsipil merupakan hal yang penting karena ketidakmampuan mengidentifikasi data dapat menggagalkan pembuktian, sehingga dalam penelitian ini identifikasi dipandang sebagai satu tahap.

Mobilisasi pengetahuan setbefore dan met-befor menurut [15], memfasilitasi pikiran selama tahap prosedur. Tetapi [13] memandang mobilisasi dan reorganisasi merupakan tahap tersendiri dalam penyusunan bukti. Mobilisasi dan reorganisasi sebaiknya dipandang sebagai satu tahap tersendiri dalam penyusunan bukti, karena tidak pada teori Gray-Tall, hasil mobilisasi perlu direorganisasi sesuai masalah yang dihadapi. Kegiatan ini kompleks dan menjadi satu kesatuan dan dilakukan sebelum memulai membangun rangkaian bukti menurut prosedur tertentu. Tahap mobilisasi dan reorganisasi ini memiliki karakteristik:

(1) mengingat pengetahuan atau pengalaman sebelumnya, (2) memilih atau mengumpulkan pengetahuan yang relevan dengan masalah (3) mengadaptasikan pengetahuan pada data masalah (4) merumuskan konsepsi tentang masalah.

Referensi [15] tidak memandang pembuatan rencana sebagai satu tahap. Hal ini didasarkan bahwa pada penjumlahan, rencana menjumlah tidak perlu diberi perhatian. Prosedur penjumlahan itu sudah kian ada, yang penting bagaimana prosedur itu dilakukan, dan dengan melakukannya berulangakan dipahami proses menghitung dan konsep penjumlahan. Tetapi pada penjumlahan bukti, pembuatan rencana sangat penting, karena penggunaan pola penalaran tertentu membuktikan prosedur tertentu [13], [6]. Sebaliknya perlu memilih dan merencanakan pola penalaran yang digunakan. Karena itu, pembuatan rencana pembuktian sebaiknya dipandang sebagai satu tahap dalam penyusunan bukti dengan karakteristik (1) menentukan pola penalaran (2) menentukan prosedur pembuktian.

Aplikasi menjadi satu tahap juga karena merupakan satu kegiatan yang harus dilakukan meskipun identifikasi, mobilisasi dan reorganisasi serta pembuatan rencana telah dilakukan. Aplikasi merupakan satu tahap tersendiri dan berbeda dengan tahap sebelumnya, dengan karakteristik: (1) melengkapi gambar menurut rencana, (2) menuliskan langkahlangkah bukti, (3) memriksa kebenaran setiap langkah atau bagian bukti secara prosedural.

Tahap proses menurut [15] dan [16] merupakan tahap memahami prosedur dan memahami makna tiap langkah atau bagian-bagian dalam prosedur. Makna tiap langkah atau bagian-bagian dalam prosedur ini 
dikaitkan untuk selanjutnya dapat memperoleh suatu makna meenyeluruh kelak. Kegiatan berpikir ini kurang ditekankan oleh Polya. Tahap melihat kembali menurut [13] diarahkan untuk memeriksa ketepatan argumen, efektivitas, dan efisien bukti. Sedangkan memahami makna menyatu dengan pemeriksaan tiap langkah selama menyusun bukti dan melihat kembali.walaupun tidak memandang bukti sebagai prosep, [13] menjelaskan pentingnya memahami konsep maupun rangkaian bukti. Proses berpikir pada penelitian ini untuk memahami prosedur dan makna tiap bagian bukti sangat penting. Tanpa pemahaman makna, bukti hanya disimpan dalam memori dan dikenali sebagi suatu prosedur. Pemahaman makna harus perhatian dan perlu perlu diberi tahapan waktu yang cukup dan tegas. Oleh karena itu, teori Gray-Tall lebih memadai karena lebih memberi penekanan pada tahap pemahaman makna dengan penjelasan yang lebih detail. Selain itu, teori GrayTall menjelaskan cara mengonstruksi makna dalam pikiran menjadi prosep.

Pembentukan makna hingga prosep kurang tepat disederhanakan menjadi dua tahap yaitu tahap proses dan tahap prosep seperti pada teori Gray-Tall. Objek mental dalam bentuk bukti sebagai prosep dapat dikenali dalam bentuk intuitif maupun tidak intuitif. Tidak semua bukti yang dikenali oleh pikiran sebagai prosep dapat digunakan hingga level intuitif dalam memecahkan masalah. Kemampuan mengenai prosep secara intuitif (break idea). Agar suatu prosep dapat dikenali sebagai break idea, perlu proses berpikir pada tahap melihat kembali teori Polya. Menurut Polya, kegiatan-kegiatan berpikir ini sebenarnya diarahkan pada pemeriksaan kebenaran, efektivitas, dan efisiensi bukti yang telah disusun. Tahap ini dalam penelitian disebut tahap evaluasi. Istilah ini dibedakan dengan istilah yang digunakan Polya untuk menunjukkan bahwa tahap ini diarahkan untuk memperbaiki atau menghaluskan pemahaman prosedur dan makna yang telah diperoleh hingga menjadi prosep yang dapat dikenali secara intuitif.

Berdasarkan penjelasan di atas, dalam pembentukan prosep hendaknya memperhatikan tahap identifikasi, mobilisasi dan reorganisasi serta pembuatan rencana, aplikasi, pembentukan makna, evaluasi, dan break idea. Tahap pembentukan makna adalah tahap memahami makna bukti sebagai suatu prosep dengan karakteristik: (1) memahami setiap langkah atau bagian bukti, (2) mengkoordinasi atau menentukan hubungan makna antar satuan bukti, (3) ekstrak makna sebagai satu entitas. Tahap evaluasi adalah memeriksa kembali ketepatan argumen, efektivitas dan efisiensi bukti dengan karakteristik: (1) memeriksa kembali ketepatan hasil dan argumen seluruh bukti, (2) menyelesaikan kembali dengan cara berbeda, (3) memilih cara yang lebih efisien. Tahap break idea adalah tahap mengenali prosep sebagai intuitif dan dipikirkan secara proseptual dengan karakteristik: (1) menghaluskan konsep, (2) memikirkan secara fleksibel proses dan konsep, (3) memikirkan teorema atau pernyataan yang dibuktikan sebagai prosep secara otomatis (intitif).

Moore dalam [17] menyatakan bahwa kesulitan mahasiswa dalam menyusun bukti disebabkan (1) mahasiswa tidak tahu mengawali 
pembuktian, (2) ketidakmampuan mahasiswa dalam memahami dan menyatakan definisi, (3) keterbatasan intuisi mahasiswa terkait dengankonsep, (4) ketidakmampuan atau ketidakmauan mahasiswa membangun suatu contoh sendiri untuk memperjelas pembuktian, (5) keterbatasan gambaran konsep yang dimiliki mahasiswa untuk menyusun suatu pembuktian, (6) ketidakmampuan mahasiswa memanfaatkan definisi untuk menyusun bukti lengkap,

Kekurangpahaman penggunaan bahasa dan notasi matematis.

Hasil penelitian yang dilakukan oleh [18] menunjukkan bahwa sebagian besar calon guru di Jerman tidak dapat menyusun secara tuntas pembuktian formal untuk materi matematika sekolah menengah. Rekomendasi dari hasil penelitian tersebut adalah hendaknya ada tindakan terprogram bagi mahasiswa calon guru matematika untuk memastikan bahwa pada saatnya menjadi guru, mereka dapat mengerjakan bukti matematis secara tepat. Pengalaman belajar pembuktian pada saat menjadi mahasiswa akan menjadikan mereka lebih siap dalam mengajarkan pembuktian matematis kepada peserta didiknya.

Komponen utama dalam kematangan bermatematika dalam pendidikan tinggi adalah kemampuan pembuktian, berpikir logis, kritis, kreatif, dan penalaran yang terkait dalam memahami dan melakukan pembuktian. Fokus dari kematangan bermatematika adalah kemampuan membaca dan menulis materi matematika serta kemampuan untuk belajar matematika menggunakan berbagai sumber daya yang tersedia. Dosen harus mengupayakan terciptanya kondisi yang mendukung agar mahasiswa mendapatkan pengalaman belajar yang secara sistematik mengarahkan ke tingkat kematangan yang lebih tinggi [19].

Motivation to Reasioning and Proving Task (MRPT) merupakan jenis tugas yang memenuhi salah satu dari 3 tipe, yakni (1) tugas yang terlihat memiliki solusi yang mudah, tetapi setelah berurusan dengan permasalahan secara mendalam, tugas tersebut memerlukan kecermatan yang tinggi, (2) tugas yang sepertinya dapat diselesaikan secara intuitif, tetapi kebenaran ituisi tersebut kurang meyakinkan, (3) tugas yang memiliki beberapa kemungkinan solusi dan menuntut mahasiswa untuk memutuskan mana jawaban yang tepat [20].

Hasil penelitian yang dilakukan oleh Takac [20] adalah pemberian tugas bertipe MRP dapat membantu siswa meningkatkan motivasi dan menyadari pentingnya menyadari pembuktian dalam matematika. Pemberian MRP dapat mengembangkan motivasi intrinsik siswa untuk membuktikan dan motivasi intrinsik merupakan langkah penting agar siswa dapat termotivasi untuk mengkreasi bukti yang benar di pembelajaranpembelajaran berikutnya. Hasil penelitian Takac juga menunjukkan bahwa pemberian MRPT dapat mengembangkan cara berpikir kritis siswa. Siswa menjadi sadar bahwa mereka perlu memverifikasi pandangan, pernyataan, atau informasi orang lain sebelum diterima. Cara berpikir kritis ini penting tidak hanya dalam matematika tetapi juga dalam kehidupan sehari-hari. 
Berdasarkan uraian di atas, perlu suatu upaya untuk meningkatkan kemampuan calon guru dalam melakukan pembuktian yang salah satunya dapat dilakuan dengan pemberian pengalaman belajar mengkonstruksi bukti matematis dengan karakter soal MRP Tasks. Upaya tersebut dapat dilakukan pada matakuliah aljabar linier yang merupakan salah satu matakuliah yang menekankan penalaran dan pembuktian matematis.

\section{Metode Penelitian}

Penelitian ini termasuk dalam eksploratif karena memaparkan hasil kajian suatu peristiwa. Metode yang digunakan dalam penelitian ini adalah grounded theory melalui 3 tahap yakni open coding, selective coding, dan theoretical coding. Merujuk pada [21] yang mengemukakan tahapan dalam penelitian meliputi (1) Open coding, pada tahap ini dilakukan pengumpulan data awal. Data awal didapat dari hasil kinerja mahasiswa mengonstruksi bukti matematis aritmatika matriks. Hasil kinerja mahsiswa tersebut dianalisis berdasarkan kaidah pembuktian yang berlaku. Kemudian dilakukan identifikasi kategori dan dilakukan pertimbangan sub kategori untuk menentukan kategori inti, (2) Selective Coding, pada tahap ini dilakukan interview untuk mengkonfirmasi hasil analisis konstruksi bukti oleh beberapa mahasiswa berdasarkan kategori inti dan pemadatan/pendalaman kategori inti, (3) Theoritical Coding, pada tahap ini dilakukan penyusunan teori.

Subjek penelitian adalah mahasiswa peserta matakuliah Aljabar Linier tahun akademik 2015/2016 di Program Studi Pendidikan Matematika IKIP PGRI Bojonegoro sebanyak 43 mahasiswa. Rancangan dalam penelitian ini dilakukan melalui penjenjangan yang terdiri dari 3 tingkatan (tinggi, sedang, rendah) berdasarkan tes akhir pembelajaran Aljabar Linier pada pokok bahasan sistem persamaan linier. Sampel teoritis diambil 9 mahasiswa terdiri dari 3 mahasiswa dari kelompok tinggi, 3 mahasiswa dari kelompok sedang, dan 3 mahasiswa dari kelompok rendah. Instrumen dalam penelitian ini adalah peneliti sebagai instrumen utama dilengkapi dengan tes konstruksi bukti matematis dan pedoman interview. Instrumen tes konstruksi bukti matematis diujicobakan terlebih dahulu pada kelas lain. Hasil uji coba adalah sebagai

TABEL 2 HASIL UJI COBA TES KONSTRUKSI BUKTI

\begin{tabular}{|l|c|c|c|}
\hline Nomor Soal & 1 & 2 & 3 \\
\hline Indeks Validitas & 0,523 & 0,630 & 0,369 \\
Kriteria* & Valid & Valid & Valid \\
Daya Pembeda & 0,53 & 0,37 & 0,48 \\
Kriteria* & Baik & Cukup & Baik \\
Tingkat Kesukaran & 0,57 & 0,13 & 0,23 \\
Kriteria* & Sedang & Sukar & Sukar \\
Reliabilitas & 0,735 & & \\
Kriteria* & Tinggi & & \\
\hline
\end{tabular}

*Kriteria validitas, daya pembeda, dan tingkat kesukaran merujuk [22]. Kriteria reliabilitas merujuk pada [23]. 
Berdasarkan hasil uji coba, ketiga soal konstruksi bukti telah memenuhi sebagai instrumen yang baik..

\section{Hasil dan Pembahasan}

\section{A. Hasil}

Berdasarkan analisis pekerjaan mahasiswa dalam mengonstruksikan bukti matematis didapat bahwa setiap siswa memiliki cara yang berbeda. Tahap open coding dilakukan dengan menganalisis pekerjaan mahasiswa dalam mengonstruksi bukti untuk mendapatkan jawaban mengenai:

1) Apakah langkah awal (pengidentifikasian) yang dituliskan mengarah ke konstruksi bukti yang tepat?

2) Strategi pembuktian manakah yang dipilih (pengidentifikasian)? Apakah strategi pembuktian langsung, tidak langsung (menyangkal) atau strategi yang lain? Bagaimanakah penggunaan strategi yang digunakan?

3) Pada aspek mobilisasi dan reorganisasi pengetahuan, seberapa tinggi tingkat pemahaman terhadap asumsi atau hal-hal yang diketahui dalam soal, serta sejauh mana kecermatan mahasiswa dalam memanfaatkan tersebut?

4) Seberapa tinggi keakuratan mahasiswa dalam menyusun atau menuliskan argumen dalam pembuatan rencana? Apakah yang disampaikan valid dan bermakna dalam jangkauan pemahaman komunitas kelas?

5) Bagaimanakah pembentukan makna yang tergambar pada alur berpikir (proses) dalam keseluruhan pekerjaan? Apakah alur berpikir tergambar dengan runtut atau terdapat lompatan logika?

6) Seberapa banyak ekspresi (kata/frase) kunci yang muncul dalam pembuktian?

7) Apakah notasi, istilah, dan simbol matematik digunakan secara tepat?

8) Bagaimanakah tingkat penguasaan dan pemanfaatan konsep-konsep terkait yang diperlukan dalam mengontruksi bukti (evaluasi)?

9) Apakah bahasa pembuktian yang digunakan menggunakan kalimat atau ekspresi yang tepat dan bermakna dalam jangkauan komunitas kelas?

Pengkajian lebih lanjut untuk mendapatkan kantegori inti dilakukan dengan penelaahan lebih mendalam dari temuan awal guna mengetahui tingkat keberagaman kualitas pekerjaan mahasiswa. Temuan awal didalami dengan mengkaji contoh-contoh spesifik pekerjaan mahsiswa yang menunjukkan beragam tingkat kesalahan mahasiswa. Setiap tingkatan diambil masing-masing 3 sampel untuk didalami terkait dengan temuan pada tahap open coding.

Kategori merupakan fokus pendalaman sebagai dasar penyusunan kojektur yang akan dikembangkan. Kategori ini disusun berdasarkan temuan yang diperoleh pada tahap open coding. Pada tahap selective coding, dilakukan 
penentuan dan pendalaman terhadap kategori inti yang diperoleh dalam tahap open coding. Uraian pada tahap open coding, menunjukkan keberagaman kualitas pekerjaan mahasiswa sesuai dalam tingkat kesalahan yang dilakukan. Secara ringkas presentase kesalahan mahasiswa dari konstruksi bukti terhadap 3 butir soal disajikan sebagai berikut.

TABEL 3 PRESENTASE TEMUAN KESALAHAN KONSTRUKSI BUKTI



Berdasarkan 9 analisis pada tahap open coding menunjukkan adanya beberapa yang saling terkait dan mengarah pada kategori. Strategi pembuktian pada kode ke-2, berkaitan langsung dengan alur berpikir (proses) pembukltian pada kode ke-5, sehingga dapat dipandang sebagai satu kategori yakni alur pembuktian. Pemahaman dan kecermatan dalam memanfaatkan asusmsi atau hal yang sudah diketahui pada kodeke-3 berkaitan langsung dengan penguasaan dan pemanfaatan konsep-konsep atau prinsip yang relevan pada kode ke-8, sehingga dapat dipandang sebagai satu kategori yakni konsep terkait. Penggunaan notasi, istilah, dan simbol matematik pada kode ke-7, berkaitan langsung dengan penggunaan bahasa konstruksi bukti yang telah ditet pada kode ke-9, sehingga dapat dipandang sebagai satu kategori yakni bahasa pembuktian. Kode yang lain masing-masing menunjukkan satu kategori yakni bahasa pembuktian. Kode yang lain masing-masing merupakan satu kategori yang perlu dikaji dan diperdalam lebih lanjut.

Kajian yang ditetapkan memerlukan pendalaman melalui triangulasi data untuk membangun suatu konjektur yang kuat. Triangulasi data dalam penelitian ini dilakukan melalui analisis pekerjaan konstruksi bukti yang dituliskan oleh mahasiswa dan interview dengan responden sesuai dengan jenjang kemampuan yang telah 
ditetapkan. Interview peneliti dengan masing-masing responden ditunjukkan untuk mengungkap pendapat mahasiswa terhadap pekerjaan yang telah dituliskan, terkait dengan 6 kategori yang telah ditetapkan.

Pendalaman kajian inti untuk berbagai tingkat kemampuan mahasiswa untuk mendapatkan gambaran menyeluruh mengenai kemampuan konstruksi bukti. Berdasarkan hal tersebut, dilakukan kajian kategori inti pada 3 level kemampuan mahasiswa dalam mengonstruksi bukti. Kriteria penentuan level didasarkan pada capaian nilai mahasiswa pada tiga soal yang ditunjukkan sebagai berikut.

TABEL 4 HASIL TES KEMAMPUAN KONSTRUKSI BUKTI

\begin{tabular}{|l|rr|}
\hline \multicolumn{1}{|c|}{ Rincian } & Data \\
\hline Banyak soal & & 3 \\
Banyak mahasiswa & & 43 \\
Nilai terendah & 40 \\
Nilai tertinggi & 76 \\
Nilai rata-rata $(\bar{x})$ & 63,56 \\
Standar Deviasi (SI) & 8,58 \\
\hline
\end{tabular}

Berdasarkan capaian nilai tersebut, mahasiswa dikelompokkan menjadi 3 level kemampuan konstruksi bukti. Merujuk pada Arikunto (2012) pemilihan kelompok menggunakan aturan.
1) Kelompok rendah dengan nilai kurang dari atau sama dengan $\bar{x}$ SD

2) Kelompok sedang dengan nilai lebih dari $\bar{x}$-SD kurang dari atau sama dengan $\bar{x}+\mathrm{SD}$, dan

3) Kelompok tinggi dengan nilai lebih dari $\bar{x}+$ SD

TABEL 5 PENGELOMPOKAN KEMAMPUAN KONSTRUKSI BUKTI

\begin{tabular}{|l|c|c|}
\hline Kelompok & Batasan nilai $(\mathrm{x})$ & Banyak mahasiswa \\
\hline Rendah & $\mathrm{x} \leq 54,98$ & 6 \\
Sedang & $54,98>\mathrm{x} \leq 72,14$ & 33 \\
Tinggi & $\mathrm{x}>72,14$ & 4 \\
\hline
\end{tabular}

Setiap kelompok dipilih 3 mahasiswa sebagai responden penelitian dengan pemilihan sampel mempertimbangkan jarak nilai antar kelompok untuk memaksimalkan informasi yang berbeda. Interview dilakukan oleh peneliti dengan kesembilan mahasiswa terpilih untuk melakukan pendalaman terhadap kategori yang telah ditentukan. Peneliti menanyakan pekerjaan mahasiswa tersebut dengan menampilkan pada layar liquid crystal display dan merekam menggunakan alat audio visual recorder dan audio recording. Peneliti menggunakan pedoman interview dan mengembangkan tanya jawab (metode semi terstruktur) sesuai dengan 
tanggapan responden dan temuan pada saat interview.

Berdasarkan kajian melalui langkah open coding, selective coding, dan theoritical coding dapat disimpulkan bahwa keberagaman kemampuan konstruksi bukti matematis pada aritmatika matriks ditentukan berdasarkan 6 kategori yakni (1) langkah awal, (2) alur pembuktian, (3) konsep terkait, (4) argumen, (5) ekspresi kunci, (6) bahasa pembuktian.

\section{B. Pembahasan}

\section{Hasil}

penelitian

berdasarkan 6 kategori yakni (1) langkah awal, (2) alur pembuktian, (3) konsep terkait, (4) argumen, (5) ekspresi kunci, (6) bahasa pembuktian. Kemampuan konstruksi bukti untuk setiap level tinggi, sedang, dan rendah adalah sebagai berikut.

1. Langkah awal

Mahasiswa dengan kemampuan konstruksi bukti level tinggi memiliki ciri-ciri: a) mampu menngidentifikasi asumsi atau hal yang diketahui dalam pernyataan yang akan dibuktikan dan memanfaatkan dengan tepat sebagai modal dalam menentukan langkah awal, b) menjabarkan asumsi atau hal yang diketahui dalam pernyataan yang akan dibuktikan ke dalam bentuk operasional dalam langkah awal pembuktian.

Mahasiswa dengan kemampuan konstruksi bukti level sedang memiliki ciri-ciri: a) memiliki kelemahan dalam mengidentifikasi asumsi atau hal yang diketahui dalam pernyataan yang akan dibuktikan sehingga penentuan langkah awal yang digunakan kurang tepat, b) mengalami kekurangtepatan dalam menjabarkan asumsi atau hal yang diketahui dalam pernyataan yang dibuktikan ke dalam bentuk operasional dalam langkah awal pembuktian.

Mahasiswa dengan

kemampuan konstruksi bukti level rendah memiliki ciri-ciri tidak mampu mengidentifikasi asumsi atau hal yang diketahui dalam pernyataan yang akan dibuktikan ke dalam bentuk operasional langkah awal pembuktian sehingga mengalami kesalahan.

2. Alur Pembuktian

Mahasiswaa dengan kemampuan konstruksi bukti level tinggi memiliki ciri-ciri: a) menggunakan strategi pembuktian yang jelas dan beragam b) konstruksi bukti yang disusun mencerminkan alur berpikir yang runtut dan logis.

Mahasiswaa dengan kemampuan konstruksi bukti level sedang memiliki ciri-ciri: a) menggunakan strategi pembuktian yang tidak jelas pada satu tipe strategi pembuktian b) konstruksi bukti yang disusun mencerminkan alur berpikir yang kurang sistematis pada keseluruhan alur pembuktian.

Mahasiswaa dengan kemampuan konstruksi bukti 
level rendah memiliki ciri-ciri: a) ketidakmampuan menggunakan strategi pembuktian b) konstruksi bukti yang disusun mencerminkan alur berpikir yang tidak sistematis dan tidak logis pada keseluruhan alur pembuktian.

3. Penguasaan Konsep Terkait Mahasiswaa dengan kemampuan konstruksi bukti level tinggi memiliki ciri-ciri: a) memahami dan menguasai semua konsep terkait dengan pembuktian b) mampu memanfaatkan konsep terkait ketika melakukan proses pembuktian.

Mahasiswaa dengan kemampuan konstruksi bukti level sedang memiliki ciri-ciri: a) memahami dan menguasai sebagian konsep terkait dengan pembuktian b) ketidakaturan pemanfaatan konsep terkait ketika melakukan proses pembuktian.

Mahasiswaa dengan kemampuan konstruksi bukti level rendah memiliki ciri-ciri: a) tidak memahami dan menguasai semua konsep terkait dengan pembuktian b) tidak mampu memanfaatkan konsep terkait ketika melakukan proses pembuktian.

4. Mengemukakan Argumen

Mahasiswa dengan
kemampuan konstruksi bukti
level tinggi memiliki ciri-ciri: a)
mampu menyusun argumen
dengan tepat b) argumen
dituliskan pada hal-hal yang
perlu dijelaskan.

\begin{abstract}
Mahasiswaa dengan
kemampuan konstruksi bukti level sedang memiliki ciri-ciri: terdapat beberapa argumen dengan kurang tepat (tingkat akulturasinya rendah).

Mahasiswaa dengan

kemampuan konstruksi bukti level rendah memiliki ciri-ciri: a) tidak mampu berargumen secara tepat b) argumen yang dituliskan pada hal-hal yang perlu dijelaskan salah.
\end{abstract}

5. Ekspresi kunci

Ekspresi kunci pada mahasiswaa dengan kemampuan konstruksi bukti level tinggi memiliki ciri-ciri semua ekspresi kunci muncul pada setiap pembuktian dengan tepat.

Mahasiswaa dengan kemampuan konstruksi bukti level sedang memiliki ciri-ciri: a) ekspresi kunci yang muncul dalam pembuktian tidak mencakup secara keseluruhan, b) terdapat ekspresi kunci yang muncul tetapi tidak tepat.

Mahasiswaa dengan kemampuan konstruksi bukti level rendah memiliki ciri-ciri: a) tidak terdapat ekspresi kunci yang muncul dalam pembuktian, b) ekspresi kunci yang muncul tetapi tidak tepat.

6. Bahasa Pembuktian

Mahasiswa dengan kemampuan konstruksi bukti level tinggi memiliki ciri-ciri: a) menggunakan bahasa pembuktian yang bermakna (dapat dipahami oleh komunitas kelas) b) notasi, istilah, dan simbol matematik yang 
digunakan dalam pembuktian ditulis dengan tepat.

$$
\text { Mahasiswaa dengan }
$$

kemampuan konstruksi bukti level sedang memiliki ciri-ciri: a) menggunakan bahasa pembuktian yang sebagian bermakna (dapat dipahami oleh komunitas kelas) b) terdapat beberapa kesalahan dalam menuliskan notasi, istilah, dan simbol matematik yang digunakan dalam pembuktian.

Mahasiswaa dengan kemampuan konstruksi bukti level rendah memiliki ciri-ciri: a) tidak menggunakan bahasa pembuktian yang bermakna (dapat dipahami oleh komunitas kelas) b) notasi, istilah, dan simbol matematik yang digunakan dalam pembuktian ditulis dengan kurang tepat.

\section{SimpUlan DAN SARAN}

Berdasarkan analisis data dan pendalaman terhadap temuan penelitian diperoleh simpulan bahwa dalam mengkonstruksi bukti matematis pada matakuliah aljabar linier yang digolongkan dalam 3 kelompok, yakni tinggi, sedang, dan rendah, dapat dikategorikan dalam (1) langkah awal, (2) alur pembuktian, (3) konsep terkait, (4) argumen, (5) ekspresi kunci, (6) bahasa pembuktian.

Berdasarkan enam

kategori tersebut, hendaknya dalam melakukan pembuktian menjadikan enam kategori tersebut sebagai pedoman dalam proses kontruksi bukti dan sebagai alat untuk merefleksi terhadap konstruksi bukti matematis.

\section{Daftar Pustaka}

Findel, B. R. Learning and Understanding in Abstract Algebra. Australia: New Hampshire. 2001.

Tall, D. From School to University: The Effects of LEarning Styles in the Transition from Elementary to Advanced Mathematical Thinking. Dalam M. O. Thomas (Penyunt.), The Seventh Annual Australasian Bridging Network Mathematics Conference (hal. 9-26). Australia: University of Auckland. 1997.

Finlow, B. K. Investigating Nation of Proof: A Study of Student's Proof Activities within the Contextof a Falliblist and Society Theory. Australia: South Bank University. 1996.

Sabri. Prospective Secondary School Teachers' Conceptions of Mathematical Proof in Indonesia. Amerika: Curtin University. 2003.

Velleman, Daniel J. How to Proof it a Structured Approach. 2th ed. New York: Cambridge University Press. 2009.

Solow, Daniel. How to Read and Do Proof. 5th ed. Cleveland: John Wiley \& Sons, Inc. 2010.

Hanna, Gila, et al. Explanation and Proof in Mathematics. New York: Springer. 2010.

Cyr, Stephane. Development of Beggining Skills in Proving and Proof Writting by Elementary School Student. www.cerme7.univ.rzeszow.p1/WG/1 /Cerme7_WG1_Cyr.pdf. 2013. (diakses 4 Agustus 2015). 
Hanna, G., \& Jahnke, N. Proof and Proving. Dalam A. J. Bishop, International Handbook of Mathematics Education (hal. 235253). Dordrecht: Kluwer Academic Publishers. 1996.

Suryadi, Didi. Model Bahan Ajar dan Kerangka Kerja Pedagogi Matematika untuk

Menumbuhkembangkan

Kemampuan Berpikir Matematik Tingkat Tinggi. Laporan Penelitian. http://didi-

suryadi.staf.upi/edu/artikel/. 2007. (diakses 4 Agustus 2015).

Alcock, L., \& Weber, K. Referential and Sintactic Approches to Proof: Case Studies from a Transitision Course. Dalam H. In Chick, \& J. Vincent (Penyunt.), Proceeding of the 29th Conference Group for the Psychology of Mathematics Education (hal. 33-40). Melbourne : Australia. 2005.

Chin, E.-T. Mathematical Proof as Formal Procept in Advanced Mathematical Thinking. Shanghai, http://online.trc.edu/PME2003/PDF/ RR_chin.pdf, China. 2003. (diakses 4 Agustus 2015).

Polya, G. Hoe to Solve it (New Mathematical Method). Second Edition. New Jersey: Prence University Press. 1997.

Gray, E. M., \& Tall, D. O. Duality,Ambiguity and Flexibility: A Proceptual View of Simple Arithmetic. Journal for Research Mathematics Education , 115-141. 1994.

Gray, E., \& Tall, D. Abstraction as a Natural Process of Mental Compression. Mathematics
Education Research Journal , 23-40. 2007.

Tall, D. O. The Transition to Formal Thinking in Mathematics. Mathematics Education Research Journal, 5-24. 2008.

Spronsen, Hillary Dee Van. Proof Processes of Novice Mathematics Education. The University of Montana Missoula, MT. 2008.

Schwarz, Björn \& Kaiser, Gabriele. Professioanal Competence of Future Mathematics Teachers on Argumentation and Proof and How Evaluate It. Proceedings of the ICMI Study 19 Conference: Proof and Proving in Mathematics Education. 2009.

Moursund, Dave. Computational Thinking and Math Maturity. University of Oregon, Eugene, Oregon 97403. 2007.

Takac, Zdenco. Influence of MRP Tasks on Student's Willingness to Reasioning and Proving. Proceedings of the ICMI Study 19 Conference: Proof and Proving in Mathematics Education. 2009.

Jones, Michael and Aloy, Irit. Guiding the Use of Grounded Theory in Doctoral Studies. International Journal of Doctoral Studies. 6 (N/A), 95-114. 2011.

Arikunto, Suharsimi. Dasar-dasar Evaluasi Pendidikan (Edisi 2). Jakarta: Bumi Aksara. 2012.

Ruseffendi, E.T. Dasar-dasar Penelitian Pendidikan \& Bidang Non-Eksakta Lainnya. Bandung: Tarsito. 2010. 
